\title{
BUCHBESPRECHUNGEN / BOOK REVIEWS
}

\author{
Patricia Graf / Thomas Stehnken (Hrsg.)
}

\section{Lateinamerika. Politik, Wirtschaft und Gesellschaft}

Festschrift für Andreas Boeckh

Baden-Baden 2008, 244 S., 45,00 EUR; ISBN 978-3-8329-3432-3

2008 wurde der Politikwissenschaftler Andreas Boeckh an der Universität Tübingen emeritiert, wo er einen der ganz wenigen Lehrstühle einnahm, die sich in seinem Fach speziell mit Lateinamerika beschäftigen. Die war ein Anlass für Schüler, Kollegen und Freunde des Wissenschaftlers, eine Festschrift vorzulegen.

Patricia Graf und Thomas Stehnken, denen es zu verdanken ist, dass die Publikation zeitnah veröffentlicht wurde, stellen den Band in der Einleitung in den Kontext der deutschsprachigen Lateinamerikaforschung. Sie weisen darauf hin, dass die Regionalwissenschaften (richtiger: Regionalforschung) stark personenabhängig sind und der Trend in den 1990er Jahren nicht zugunsten Lateinamerikas verlief. Nach einem Aufsatz von Manfred Mols „Lateinamerikas Einheit und ihr Trend zum Verfall“, in dem er auf die Vagheit des lateinamerikanischen Integrationsprojektes verweist und der mit einem eher skeptischen Blick auf die Perspektiven der Integration endet, ist der Band in drei Abschnitte gegliedert, in denen die Forschungsinteressen von Boeckh zum Ausdruck kommen.

Staat und Herrschaft bilden den ersten Abschnitt. Hans-Jürgen Burchhardt stellt neue Fragen an die Demokratieforschung. Im deutschsprachigen Bereich dominiere nach wie vor die Transitionsforschung, zumal im Bertelsmann Transformation Index (BTI) ein universalistischer Begriff der „Marktdemokratie“ vorherrsche. Andere Entwicklungen - wie der neue Populismus und sein teilweise rhetorisches Bekenntnis zu mehr Staat - kämen damit zu kurz. Seine Schlussfolgerung: „Das Verhältnis von Demokratie und Wirtschaft muss neu gedacht werden“ (S. 49). Dem nicht nur in der deutschsprachigen Lateinamerikaforschung sträflich vernachlässigtem Thema der Steuern und Steuerpolitik wendet sich Christian von Haldenwang zu. Bekanntermaßen leistet die reiche Oberschicht dort einen sehr geringen Beitrag zur Finanzierung öffentlicher Güter und wenn überhaupt, dann lieber in Form von Spenden oder durch die Errichtung von Stiftungen. Die hohen Wachstumsraten seit 2003 haben bei vielen Regierungen Höhenflüge befördert, statt die Grundlagen für eine nachhaltige Fiskalpolitik zu legen. Auch dieses Thema gewinnt durch die weltwirtschaftliche Entwicklung in der zweiten Hälfte des Jahres 2008 zusätzliche Bedeutung. Von einer gewissen Kühnheit beflügelt scheint auf den ersten Blick der Vergleich zwischen Kolumbien und Burkina Faso zu sein, den Michael Rösch unternimmt. Allerdings nehmen beide Staaten auf dem Failed State Index 2007 gemeinsam Rang 33 ein. Die Übereinstimmungen, so der Autor, seien jedoch gering. Nicht zuletzt aufgrund der Tatsache, dass nach den Ergebnissen der Einstellungsforschung viele Kolumbianer der Meinung sind, die Lage in ihrem Land 
habe sich durchaus verbessert. Seinem Fazit „Ouagadougou ist nicht Bogotá“ (S. 94) wird wahrscheinlich jeder, der sich ernsthaft mit Regionen beschäftigt, zustimmen. Karl Buck geht in seinem Artikel auf die strategische Partnerschaft zwischen der EU, Lateinamerika und der Karibik ein und plädiert für eine Verbesserung der Kooperation.

Insgesamt eher skeptisch fallen die vier Beiträge im zweiten Abschnitt zu Wirtschaft und Gesellschaft aus. Im internationalen Vergleich wendet Lateinamerika nur relativ geringe Mittel für Forschung und Entwicklung (F\&E) auf. Hartmut Sangmeister konstatiert, weite Teile Lateinamerikas in der Weltkarte des technologischen Fortschritts seien weiße Flecken. Nachhaltige Verbesserungen mit Blick auf die internationale Wettbewerbsfähigkeit sind ausgeblieben. Und die vielfach gelobte Entwicklung im Bereich der Biokraftstoffe in Brasilien? In seiner detail- und kartenreichen Analyse muss Gerd Kohlhepp hier zumindest ein Fragezeichen stehen lassen. Die Steigerung der Exporteinnahmen folgt der Logik des transnational vernetzten Agrobusiness, die eigene Regierung wiederum präsentiert Brasilien gerne als „Weltmacht des 21. Jahrhunderts für erneuerbare Energien“. Zukunftsweisend könnte sich die ab ca. 2010 erwartete Herstellung von Biokraftstoffen der zweiten Generation erweisen, erst dann ist wohl ein abschließendes Urteil möglich. Als schlecht wachsende Pflanze hat sich in der Vergangenheit der Ölsegen in Venezuela gezeigt. Die schon 1936 ausgegebene Parole „Das Öl aussäen“ hat nur teilweise funktioniert, gleichzeitig aber hohe Erwartungshaltungen an den Staat und die Politiker gefördert. Chávez' staatszentrierte Ölpolitik erscheint Heinz G. Preuße mehr eine Rückkehr zu den durchwachsenen Erfahrungen des 20. Jahrhunderts zu sein als ein Vorgriff auf eine bessere Sozialpolitik für die Zukunft. Monica Rubiolo erkennt durchaus Ansätze zu einem effektiveren Public Financial Management in Nicaragua. Auch in diesem Land und Bereich erfordert es „mehr Transparenz, Effizienz und Effektivität in der öffentlichen Tätigkeit“" (S. 188).

Um Kultur und Gesellschaft geht es im dritten Abschnitt. Ohne Zweifel zählt der Populismus in vielen Ländern zur politischen Kultur. Friedrich Welsch und Héctor Briceño zeigen am Beispiel Venezuelas u.a. mit Hilfe der Ergebnisse empirischer Einstellungsforschung, dass die Venezolaner sowohl für den Populismus als auch für die Demokratie eintreten. Die Neigung zum Populismus und die Fixierung auf den Staat vermindern sich mit steigendem Bildungsgrad und Einkommen. Vor diesem Hintergrund wünschen sich die Autoren für den lateinamerikanischen Populismus mehr Demokratie. Und welche Rolle spielen die Eliten in diesem Zusammenhang? Sie stellen ein insgesamt in der internationalen Lateinamerikaforschung stiefmütterlich behandeltes Thema dar. Der in Westeuropa nach 1945 üblich gewordene Begriff der Funktionselite greift zu kurz, da dort der Rechtsstaat in den meisten Gesellschaften auf seine Durchsetzung wartet und der Staat nach wie vor stark von traditionellen Klientelnetzen durchzogen bleibt. Hinzu kommt, dass eine objektive Elitenanalyse in einigen Ländern für die Forscher nicht ganz folgenlos sein kann. Die Unzulänglichkeiten der Politikwissenschaft resultieren nach Ansicht von H.C.F. Mansilla nicht zuletzt aus der mangelnden Analyse des kollektiven Selbstverständnisses. Denn „Naivität fast aller Bevölkerungsschichten“, so sein Schlusssatz, ,,bildet die gemein- 
same Grundlage sowohl des korrupten Neoliberalismus als auch des autoritären Neopopulismus“ (S. 214). Rafael Sevilla formuliert „Anmerkungen zur Identität und Literatur in Lateinamerika" mit einem Beispiel aus Chile. Dana de la Fontaine analysiert verschiedene Formen der Interaktion zwischen Zivilgesellschaft und sozialen Bewegungen am Beispiel von Guatemala, Brasilien, Bolivien und dem Sonderfall einer populistischen Variante in Venezuela. Es zeichnet sich ein Trend zur „Semi-Institutionalisierung“ von sozialen Bewegungen ab, die mit den traditionellen politischen Eliten eine Koexistenz eingehen.

Die drei Bereiche sind Beispiele für Themen, die sinnvollerweise auch in Zukunft an deutschen Universitäten behandelt werden sollten. Immerhin wächst die spanischsprachige Bevölkerung weltweit, was sich in der Expansion des Cervantes-Instituts in Europa und dem anhaltenden Lateinamerika-Interesse an nordamerikanischen Universitäten manifestiert. Auch in Deutschland haben vor allem Studierende etwa in Passau oder jüngst in Bonn erfolgreiche Initiativen mit Blick auf Latein- und Iberoamerika ins Leben gerufen. An der Universität Tübingen wird in Zukunft die entsprechende institutionelle Anbindung fehlen: Nach Mainz, Heidelberg und Augsburg wurde auch dort die vakant gewordene Professur nicht mehr mit einem Lateinamerika-Experten besetzt.

Nikolaus Werz, Rostock

\section{Stefan Kadelbach / Parinas Parhisi (Hrsg.)}

\section{Die Freiheit der Religion im europäischen Verfassungsrecht}

Schriften zur europäischen Integration und Internationalen Wirtschaftordnung, Bd. 9

Baden-Baden, Nomos-Verlagsgesellschaft, 2007, 194 S., 39,00 EUR;

ISBN 978-3-8329-2947-3

Um die Freiheit der Religion ist es in den Staaten und Gesellschaften, denen das Interesse dieser Zeitschrift gilt, höchst unterschiedlich bestellt. Das gilt aber auch für das Europa der Union und des Europarats. Religion ist den einen Sinn stiftender Halt, andere empfinden seitens der Religion belastende Ingerenz, manchmal seitens des Staates angeleitet. Immer betrifft Religion die höchst persönliche Lebensführung und Entfaltung, auf sie bezogene Freiheit, positiv wie negativ, rührt an Vorstellungen von zu lebender Würde und hat oft zu tun, dann auch praktisch-politisch, mit Meinungsfreiheit. Daher gehört die Freiheit der Religion zu denjenigen Menschenrechten, deren Zustand im jeweiligen Staat und deren Verwirklichungsgrad Rückschlüsse auf die Menschenrechtslage im Allgemeinen vermitteln. Nicht selten geht von der Religionsfreiheit Gefährdungspotential für die jeweils Herrschenden aus, manchmal für ganze Systeme.

Sahen wir praktisch gelebte Religionen, aber auch Konfliktlagen einer Auseinandersetzung mit religiösen Ambitionen anderer, im westlichen Europa für längere Zeit eher auf dem Rückzug, im in Sozialismen verfassten Osten ohnehin, so ist dies hier wie dort teils anders geworden, und außerhalb Europas ohnehin anders, gleichermaßen in die Nähe zu 
Religionen suchenden Staatswesen wie auch in den asiatischen Bastionen des Kommunismus, die eine religiöse Renaissance oder jedenfalls das Bemühen darum erleben. Das Thema „Religion und Recht“, das immer auch das Thema „Staat und organisierte Religion“ betrifft, bleibt ein Gegenstand von brennender Aktualität und gehört zu den lohnendsten im Bereich vergleichender Verfassungsbetrachtung.

Gedanken und Materialien dazu enthält der vorliegende Band. Wenn er der Freiheit der Religion „im europäischen Verfassungsrecht“ gewidmet ist, so ist das nicht sehr plastisch formuliert. Gemeint ist hier nicht „nur“ das Verfassungsrecht des integrierten Europas (das noch kein solches im formellen Sinne ist). Oft geht es in dem Band um die Europäische Menschenrechtskonvention, vielfach auch um deutsches Recht, vor allem Verfassungsrecht. Vor allem geht es um Rechtslagen und Diskussionen in Europa, meist um Christentum, aber auch um Islam, nicht eigentlich um andere Religionen. Auch methodisch und disziplinär sind die Beiträge heterogen. Sie stammen von Juristen sowie dem Religionsphilosophen Thomas M. Schmidt, erheben inhaltlich und formal teilweise rechtswissenschaftliche Ansprüche, doch sind auch plädierende Repräsentanten der beiden deutschen Großkirchen sowie ein Europapolitiker vertreten. Das alles erklärt sich auch aus der Genese des Buches, das auf zwei Tagungen an der Universität in Frankfurt am Main zurückgeht, gewidmet der Freiheit der Religionen im europäischen Verfassungsleben sowie der Thematik „Religiöse Toleranz als Herausforderung an den säkularen Staat“. Die meisten Beiträge sind ergänzte Vorträge, manche von ihnen eher knappe statements. Die Mitherausgeberin Parinas Parhisi steuert demgegenüber eine intensive, hoch interessante, reich dokumentierte Abhandlung über Frauenrechte in Iran bei, vor allem auf den Maßstab des Völkerrechts ausgerichtet.

So ist dies eine Versammlung oder Ansammlung einzelner Essays zu dem eingangs angesprochenen Großthema. Aus dem Blickwinkel dieser Zeitschrift sei ausdrücklich noch hingewiesen auf die dichte Skizze von Silvia Tellenbach zu islamrechtlichen Fragen der Abwendung vom Glauben. Weitere Beiträge (etwa der schon angesprochene Religionsphilosoph Schmidt zur Frage von Religion als vorpolitischer Quelle von Menschenrechten, Ernst Gottfried Mahrenholz zu religiöser Toleranz im säkularen Staat, Ute Sacksofsky über das Verhältnis von Regierung und weiblicher Emanzipation, Doris König über Religionsfreiheit im europäischen und deutschen Recht sowie Antje von Ungern-Sternberg über einschlägige Einflüsse der EMRK auf Großbritannien und Frankreich) liefern Bestandsaufnahmen, die willkommene Anregung vermitteln auch für den vergleichenden Blick aus Europa hinaus. In besonderem Maße gilt das auch für das energische Plädoyer von Michael Stolleis gegen die Erwähnung Gottes in einer künftigen europäischen Verfassung, die er viele werden anderer Auffassung sein - als „Abwehrzauber“ begreift.

Philip Kunig, Berlin 


\section{Atchou Sodjada Essousso}

\section{Demokratieförderung}

Politik gestalten oder beraten?

Internationale Hochschulschriften, Bd. 507

Münster, Waxmann 2008, 260 S., 34,90 EUR; ISBN 978-3-8309-2005-2

\section{Annette Jünemann / Michèle Knodt (Hrsg.)}

\section{Externe Demokratieförderung durch die Europäische Union}

Baden-Baden, Nomos 2007, 376 S.,49,00 EUR; ISBN 978-3-8329-2794-3

Entwicklungspolitik beschränkt sich schon seit gut zwei Jahrzehnten nicht mehr allein auf die bloße wirtschaftliche Entwicklung eines Staates. Bereits seit den 1980er Jahren wird intensiv diskutiert, ob etwa die internationalen Finanzinstitutionen bei der Vergabe von Darlehen auch die Menschenrechtssituation oder die Staatsform eines Staates mit in ihre Entscheidung einbeziehen sollen. Zudem ist die Demokratieförderung mittlerweile ein eigenständiger Teil vieler Entwicklungsprogramme von UNDP oder der Europäischen Union. Letztere hat teilweise Menschenrechts- und Demokratieklauseln in Kooperationsverträge mit Entwicklungsländern aufgenommen, die ihr ermöglichen, Verstöße gegen diese Standards mit wirtschaftlichen Sanktionen zu ahnden. Diese Entwicklung ist mehrfach Gegenstand juristischer Dissertationen gewesen. Hervorzuheben sind dabei in erster Linie die Monographien von Christian Pippan und Frank Hoffmeister.

Die beiden hier besprochenen Bücher beschäftigen sich mit dem Thema der Demokratisierungspolitik aus einer politikwissenschaftlichen Perspektive, nähern sich ihm aber aus unterschiedlichen Richtungen. Der Band von Annette Jünemann und Michèle Knodt widmet sich der Frage, welche Faktoren die Wahl der Instrumente bei der Demokratieförderung der Europäischen Union beeinflussen. Warum verhält sich die EU verschiedenen Ländern gegenüber unterschiedlich, obwohl die politische Situation in diesen Staaten vergleichbar ist? Die beiden Herausgeberinnen generieren dazu mehrere Hypothesen, die im Buch anhand von Fallstudien aus unterschiedlichen Staaten und Regionen getestet werden.

Demgegenüber untersucht Atchou Sodjada Essousso in seiner Dissertation das Zusammenspiel der wissenschaftlichen Aufarbeitung von Demokratisierungsprozessen und praktischer Politikberatung. Welche Bedeutung hat die Wissenschaft für die Politikberatung, und welche Rolle sollte sie spielen? Bei seiner Untersuchung stützt er sich hauptsächlich auf drei Fallstudien - die Aussetzung der Entwicklungskooperation mit Togo durch die Europäische Union (76 ff.), ein InWent-Projekt zur Förderung der kommunalen Verwaltung in Namibia (102 ff.) sowie ein Good Governance-Projekt der GTZ in Kooperation mit der Afrikanischen Union (127 ff.).

Essousso konzentriert sich dabei im wesentlichen auf zwei Bereiche, in denen die Wissenschaft einen positiven Beitrag zur Politikberatung leisten kann. Dies ist zum einen die Entwicklung von Maßstäben zur Bewertung von Regierungsformen, um den Erfolg von Demokratisierungsprozessen messen zu können. Auch wenn diese Demokratiemessung 
gewissen Grenzen unterliegt, kann sie dem Autor zufolge doch einen wichtigen Beitrag zur Projektbewertung leisten, da sie zu einer gedanklichen Präzisierung des Befundes zwinge und damit die Nachvollziehbarkeit einer Bewertung erheblich verbessere (202 f.).

Zum anderen identifiziert Essousso die politikwissenschaftliche Steuerungsdiskussion als relevanten wissenschaftlichen Beitrag für die praktische Politikberatung (204 ff.). Diese zeige auf, dass die gesellschaftliche Steuerung durch den Staat erheblichen Grenzen unterliege, derer sich die Politikberatung bewusst sein müsse, wenn sie versuche, mit politischen Reformen gewisse gesellschaftliche Ziele zu erreichen. Allerdings zeigt Essousso auch die Grenzen politischer Beratung durch die Wissenschaft auf. Diese sieht er vor allem in der unterschiedlichen Logik der verschiedenen Systeme. Zum einen sei die Wissenschaft in ihrem Erkenntnisinteresse langfristiger angelegt als die Politik (193); zum anderen gehe es der Politik in erster Linie um konkrete Entscheidungen, während die Wissenschaft allgemeine Wahrheitsfindung anstrebe. Daher empfiehlt er der Politikwissenschaft, ihre Forschung stärker auf konkrete Probleme und Empfehlungen auszurichten, um politischen Einfluss zu erlangen (195). Gleichzeitig warnt er davor, die politische Unabhängigkeit aufzugeben, um weiterhin eine kritische Distanz wahren zu können (194).

Essoussos Monographie präsentiert sich im Gewande eines großen Rundumschlags. Der Autor selbst bezeichnet seinen Ansatz als „,ganzheitlich“ (227) und streift im Rahmen seiner Untersuchung viele spannende und komplexe Fragen, die sich im Zusammenhang mit der Demokratieförderung stellen. Diese reichen von der sozio-kulturellen Bedingtheit der Demokratisierung über die kulturelle Relativität von Demokratie bis hin zu den konkreten Problemen der externen Demokratieförderung. Allerdings gelingt es dabei nicht immer, den roten Faden der Untersuchung aufzuzeigen. Viele der behandelten Themen scheinen mit der zentralen Forschungsfrage nur peripher in Zusammenhang zu stehen. Auf der anderen Seite hätte die Analyse des Zusammenhangs von Wissenschaft und Politik mehr Tiefe vertragen können. Selbst einer Schrift, die Diskussionen anstoßen möchte statt positive Resultate zu liefern (223), hätte eine stärkere Konzentration auf die zentrale Forschungsfrage gut getan.

Demgegenüber versucht der Band von Annette Jünemann und Michèle Knodt gar nicht erst, das Thema der externen Demokratieförderung umfassend zu behandeln. Vielmehr beschränkt er sich auf die Frage, welche Faktoren die Wahl der Instrumente zur Demokratieförderung durch die Europäische Union beeinflussen. Den Rahmen der Schrift bilden dabei zwei Beträge der beiden Herausgeberinnen. In der Einleitung führen sie in die Forschungsfrage ein und stellen diese in den Kontext des aktuellen Diskussionsstandes. Dabei erarbeiten sie fünf Hypothesen, die durch die konkreten Fallstudien des Buches getestet werden sollen. Die wesentlichen Faktoren für europäische Politik sollen danach die wirtschaftlichen Beziehungen mit dem Drittstaat und die Sicherheitsinteressen, die die EU in diesem verfolgt, sein (22 ff.). Diese Hypothesen stehen im Gegensatz zu prominenten Theorien, die die Europäische Union als werteorientierten außenpolitischen Akteur betrachten (12 ff.). 
Im Schlusskapitel versuchen Jünemann und Knodt die in den Fallstudien herausgearbeiteten Faktoren zu systematisieren, die die Demokratisierungspolitik der EU beeinflussen. Ein wichtiger Faktor ist dabei die gegenseitige Abhängigkeit zwischen der EU und dem Drittstaat. Je stärker die wirtschaftlichen Interessen der EU sind, oder je weniger der Drittstaat auf die EU angewiesen ist, desto weniger wahrscheinlich ist es, dass die EU negative Sanktionen ergreift (357 ff.). Sie wird in diesen Fällen positive Maßnahmen bevorzugen. Gleiches gilt, wenn die EU essentielle Sicherheitsinteressen zusammen mit dem Drittstaat verfolgt, dieser etwa ein Partner im sog. Kampf gegen Terrorismus ist (366). Einen starken Einfluss auf die Politik der EU hat zudem die Frage, ob es einen interessierten Mitgliedstaat gibt - etwa aufgrund einer Kolonialvergangenheit (353 ff.). Die Regierung dieses Staates wird die EU-Linie dabei erheblich mitbestimmen, was gewisse Divergenzen in der Reaktion der EU erklärt. Schließlich spielen auch die internen Strukturen in dem Drittstaat eine entscheidende Rolle. Da die Transition zur Demokratie immer ein sehr sensibler Prozess ist, geht die EU in politisch instabilen Staaten in der Regel mit größerer Zurückhaltung vor als in Staaten mit einer starken, autoritären Regierung (362). Diese Ergebnisse zeigen, dass die EU bei der Demokratieförderung nicht allein als werteorientierter Akteur agiert, sondern ihr Handlungsspielraum oft eingeschränkt ist - teilweise um eigene Interessen nicht zu gefährden, teilweise aus Gründen, die mit dem Drittstaat zusammenhängen.

Die einzelnen Fallstudien beschäftigen sich mit verschiedenen Ländern, wobei versucht wurde, repräsentative Beispiele für verschiedene Weltregionen zu finden. Im Folgenden sollen einige dieser Studien exemplarisch herausgegriffen und besprochen werden. Gordon Crawford beschäftigt sich in seinem Beitrag mit der Demokratieförderung in Ghana. Er stellt fest, dass die Demokratieförderung trotz sehr positiver Rahmenbedingungen nur wenige Fortschritte mache, und führt dies darauf zurück, dass die EU einen sehr instrumentellen Ansatz der Demokratieförderung verfolge, der sich vor allem durch zwei Charakteristika auszeichne: Zum einen habe die EU nur ein untergeordnetes Interesse an der Demokratieförderung, wenn sie in dem Land keine expliziten wirtschaftlichen Ziele verfolge oder konkrete Sicherheitsinteressen habe. Zum anderen sei ihr eine Politik der wirtschaftlichen Liberalisierung, die darauf abziele, staatliche Gewalt zu schwächen und die verbleibende Staatsgewalt unter formale Kontrolle zu bringen, wichtiger als eine Stärkung umfassender demokratischer Partizipation. Crawford steht dieser Entwicklung kritisch gegenüber und beklagt eine Dominanz des liberalen gegenüber dem demokratischen Element (84).

Gerade an dieser Kritik zeigt sich jedoch der schmale Grat zwischen deskriptiver Analyse von Demokratisierungsprozessen und normativer Beurteilung derselben. Es gibt in der politikwissenschaftlichen Demokratisierungstheorie durchaus Stimmen, die eine Machtdispersion für ein wesentliches Element der Demokratisierung halten (Vanhanen) und für die die Stabilisierung der ökonomischen Verhältnisse essentielle Voraussetzung einer stabilen Demokratie ist (Lipset, Przeworski et al.). Insofern kann die Strategie der Europäischen Union in Ghana nicht ohne weiteres als sachfremd und ausschließlich interessengeleitet 
kritisiert werden, lassen sich für diese doch durchaus plausible Gründe anführen. Insgesamt präsentiert Crawford jedoch eine gut strukturierte und sorgfältige Analyse, die sich vorbildlich an der übergeordneten Forschungsfrage des Bandes orientiert.

Dies gelingt leider nicht durchweg in gleicher Weise. So hält sich Franco Algieris Beitrag zu China und Myanmar zuerst mit langwierigen Definitionen europäischer Außenpolitik und der Einordnung der Demokratieförderung in den Kontext derselben auf (169 ff.). Die eigentliche Analyse der Verhältnisse in China und Myanmar ist dagegen relativ knapp gehalten und kommt zu dem wenig überraschenden Ergebnis, dass das strategische Interesse die Wahl der Instrumente bei der Demokratisierungspolitik determiniert. Die EU habe ein hohes wirtschaftliches Interesse an China, so dass selbst bei gravierenden Menschenrechtsverletzungen kaum negative Sanktionen ergriffen würden (178 f.). Myanmar sei dagegen für die EU sowohl wirtschaftlich als auch strategisch unbedeutend. Daher könne diese harte Sanktionen gegen den südostasiatischen Staat ergreifen, um die eigene Rolle als werteorientierter Akteur herauszustreichen, ohne dafür einen hohen Preis zahlen zu müssen (180).

Sabine Fischer befasst sich in ihrem Beitrag mit der Demokratisierungspolitik der EU gegenüber Russland. Nach dem Zusammenbruch der Sowjetunion schlossen Russland und die EU 1993 ein Partnerschaftsabkommen. In diesem Rahmen wurde Russland technische und finanzielle Hilfe gewährt, während dieses sich auf die Einhaltung demokratischer Standards verpflichtete. In der Praxis war die Reaktion der EU auf den Tschetschenienkrieg oder die autoritären Tendenzen in der russischen Politik nach der Wahl Putins jedoch eher schwach. Fischer führt dies im Wesentlichen auf zwei Gründe zurück. Zum einen hätten einige Mitgliedstaaten starke wirtschaftliche Interessen in Russland, die dazu führten, dass diese betroffenen Staaten negative Maßnahmen gegen Russland blockierten (256). Zum anderen seien Russlands derzeitige politische Eliten nicht sonderlich offen für externe Einflüsse. Da Russlands Wirtschaft zudem im Wachstum begriffen sei, könne es sich eine stärkere Unabhängigkeit von der EU erlauben als noch in den 1990er Jahren (259). Aufgrund dieser ungünstigen Rahmenbedingungen kommt Fischer zu dem resignierenden Schluss, dass man in Russland derzeit mit kleinen Demokratisierungsschritten zufrieden sein müsse (264).

Der Band von Jünemann und Knodt ist ein exzellentes Beispiel für gelungene Forschungskooperation in den Geisteswissenschaften. Den beiden Herausgeberinnen ist es nicht nur gelungen, eine bisher wenig beachtete Frage in dem spannenden Feld der Demokratieförderung näher zu beleuchten. Auch die Konzeption des Buches hebt sich wohltuend positiv von der vieler anderer Tagungs- und Sammelbände ab. Es wird eine konkrete Forschungsfrage definiert und in den einzelnen, zum Teil sehr lesenswerten Fallstudien näher beleuchtet. Den Herausgeberinnen gelingt es, die dabei generierten Fäden im Schlusskapitel zusammenzuführen und dem Buch somit einen überzeugenden Rahmen zu geben. Das Buch kann daher allen an dem Thema Interessierten nur wärmstens ans Herz gelegt werden. 
Heinz-Dieter Assmann / Thomas M H Chan / Karin Moser von Filseck (Eds.)

Perceptions and Images of China

Neue China-Studien, Bd. 2; Baden-Baden, Nomos Verlagsgesellschaft, 2008, 298 pp;

EUR 39,00; ISBN 978-3-8329-3459-0

\section{Hans J Giessman (Ed.)}

\section{Security Handbook 2008, Emerging Powers in East Asia: China, Russia and India, Local Conflicts and Regional Security Building in Asia's Northeast}

Baden-Baden, Nomos Verlagsgesellschaft, 2008, 256 pp, paperback; EUR 44,00;

ISBN 978-3-8329-3378-4

Asia, especially East Asia, has begun to stir again, not as an epicentre of political revolution, as with India's new-found independence in 1947, the communists' ascent to power after almost half a decade of civil war on the Chinese mainland or the North's final victory in the Vietnam War. Asia is now taking shape as a centre of economic gravity, with the "emerging" giants of China and India placing their weight beside that of Japan, today still the world's second largest economy. December 2008 marked the thirtieth anniversary of the $3^{\text {rd }}$ Plenary Session of the Central Committee of the XIII ${ }^{\text {th }}$ Congress of the Communist Party of China, when Deng Xiaoping succeeded in cementing a new departure, already initiated earlier through reforms dismantling Mao Zedong's people's communes in the countryside, which would see 'Red China' jettisoning the heavily destructive voluntarism of the Great Helmsman in favour of a course of economic reconstruction based on progressive, if often groping, strengthening of market mechanisms and - crucially - on economic co-operation with the capitalist countries no longer seen as adversaries in a contest of world revolution but as sources of technology, managerial know-how and - increasingly - as markets for the manufactures of a China turned "workshop of the world". In foreign relations, Peking's earlier rapprochement with the US against the background of Washington's Cold War confrontation with the Soviet Union and the latter-day schism between the two communist pretenders in Moscow and Peking speedily broadened into China's active participation in international affairs as an indispensable complement to the country's growing global economic ties and interests.

Re-emerging China's bulk could not fail to loom large on the world stage, and Peking's perception of foreign anxiety about "China's peaceful rise" caused official parlance to plump for a time for the seemingly more innocuous "peaceful development". These semantic contortions indicate a simple fact: China's impressively successful reforms remain accompanied by the need for further efforts to establish the country's place as a stakeholder in international relations, particularly in view of the diplomatic landscape of Asia which continues to include potentially eruptive sutures such as the Korean Peninsula, conflicting maritime territorial claims, the stand-off across the Taiwan Strait and - farther afield - the tense relationship between India and Pakistan, China's "all-weather ally", or an Afghanistan riven by internal violence. 
All national policy carries historical baggage and its inner dynamics often are not readily apparent; China is no exception: The Celestial Empire's profound discomfiture in the wake of the First Opium War with the United Kingdom (1840-42) and the ravages of internal disintegration and foreign (Japanese) aggression in the decades of 1911 to 1949 form the backdrop against which present-day "Reform and Opening", as part of the "great renaissance of the Chinese nation" ${ }^{1}$, is strongly suffused by a quest to regain past splendour. Germans, by contrast and against the background of the Hitlerite abyss in their own recent past, strenuously reassure occasional sceptics that re-unification, in 1990, of the country's western and eastern parts and integration of the reunited nation in the European Union is not meant to be a return to former great-power stature ${ }^{2}$.

Views of China, by Chinese themselves as well as by others, are likely to be complex and similarly fraught with perceived or real risk of misreading. The presentation of "Perceptions and Images of China" in the first volume under review is therefore to be welcomed as a contribution to better mutual understanding between this fast-changing quarter of humanity and the outside world. Contributions - papers presented at a 2006 conference in Hong Kong on "The Perception of China: Images of a Global Player" - are grouped into four sections, on "Economics", "Political Science", "Law Studies" and "Cultural Studies". The essays on the economy and law in particular concentrate on contemporary China while those on politics and culture draw more on historical themes. Given that continuity, change and confronting the challenges of the present are at the core of ideas formed, inside and outside China, of the country's vertiginous transformation from peasant-society-cum-Maoist-tyranny towards hi-tech creditor of the United States of America, according weight to past and present more evenly in these four sections could have avoided skewing the overall analytical perspective. Instead the book assembles texts reading like a presentation canvassing potential investors, as Li Shuoli's "The Development of a Pan-Tonkin Gulf Economic Zone and China's Five National Development Strategies", alongside Karl-Heinz Pohl's lucid philological discussion of translating classical Chinese poetry. Much old ground is re-covered in some papers, as in Liu Weijian's sweeping "Toward a Postmodern Metropolis: Representation of Shanghai in German Literature and Media"; those seeking an introduction to the subject will be well served by Gottfried-Karl Kindermann's "New China in the Perceptions of U.S. Presidents from F.D. Roosevelt to Jimmy Carter"; the pressing concerns of foreign investors regarding effective protection of intellectual property in China are succinctly described in Georg Sandberger's "The Protection of Intellectual Property Rights After the People's Republic of China's Accession to the WTO".

I much regret to say that the manuscripts of several texts in this volume should never have made it past the reader's desk: Printing errors and faulty English mar this publication all the more considering the eminent position enjoyed by Nomos as one of Germany's

Zhonghua minzu de weida fuxing, a standard element of official and media discourse.

2 Cf eg the speech by Erhard Eppler in the (then Western) German Federal Parliament (Bundestag) on 17 June 1989: "Wenn wir von Wiedervereinigung sprechen, dann hören unsere Nachbarn vor allem das "Wieder"." (In: Auswärtiges Amt, Außenpolitik der Bundesrepublik Deutschland, Dokumente von 1949 bis 1994, Köln: Verlag Wissenschaft und Politik, 1995, p 596.) 
foremost academic publishers ${ }^{3}$. It is to be hoped that considerably more editorial care will be invested in subsequent publications on a subject that richly deserves scholarly attention.

High-speed economic advances in the East Asia region have outpaced its foreign-policy foundations. The vast gains in prosperity already made and future gains on which the peoples of the region critically depend are left vulnerable to impediments of traditional emphases on national sovereignty and even notions of historic pre-eminence, to the disruptive potential of spatially limited but politically high-profile territorial disputes, and to the perils of power holders who feel boxed in by progress that has long swirled past their own sterile governance attempting to break out of their corner in dangerous fashion. ASEAN members casting their political net ever wider through dialogues with northern Asian neighbours, the slow dance of cautious partners in Central Asia in the comparatively recent Shanghai Cooperation Organization (SCO), the laborious institutionalised interaction of the Six-Party Talks on the Korean Peninsula and the first regular stand-alone meeting of the heads of government of China, Japan and the Republic of Korea in Fukuoka earlier this year represent unhurried but encouraging attempts to regularise and intensify joint political efforts.

The "Security Handbook 2008" provides a helpful snapshot of a region whose political fault lines continue to endanger its huge potential. Professor Giesmann's introductory essay gives a concise and clear overview of this structural disparity; Xia Liping and Ceng-yi Lin outline future perspectives from mainland China and Taiwan respectively. Alexandre $Y$ Mansourov's "Russia's Advances and Setbacks in Northeast Asia under President Putin (1999-2007)" describes growing commonalities in Russo-Chinese relations but also the significant caveats particularly about the imbalanced structure of bilateral trade, the competitive complications of Russia's multidirectional strategies in energy co-operation and Moscow's efforts at safeguarding Russia's strategic interests in the area of arms sales and military co-operation. Presidents Putin's "most significant triumph", of the conclusive agreement on the Russo-Chinese border, seems to have put to rest long-standing irredentist velleities on the Chinese side of the border where many continued to chafe at the Siberian

Eg, "newly gained prepare [?] property rights" (p 19), "renown boutiques" (p 20), "evacuated" [instead of 'evicted'] (p 23), "wiped [instead of 'swept'] under the rug" (p 26), "politic [instead of 'policy'] of reform" (p 126), "a society of "small comfort"" (p 127) quaintly translates the Chinese xiao kang shehui, rendered in English-language texts published in China as "moderately well-off society", "stabile [?] legal order" (p 157), "plague of Western brands" (167), "Mrd \$" [instead of 'billion'/'bn' or '1,000 million'] (p 170), "can not [sic] be satisfied" (p 170), "interdicted" [instead of 'prohibited'] (p 177), "freewill" [sic] (196), "Der rotblaue [instead of 'blaurote'] Methusalem" (p 209), "Putonhua" [instead of 'Putonghua'] (p 215), "outshined" [instead of 'outshone'] (p 234), "implementations [?] about China" (p 253), "stood in the sign of" [for "stand im Zeichen"?], "scriptures [sic] of the Jesuit missionaries" (p 254), "Shengdu" [instead of 'Chengdu'?] (p 266), "the Great Revolution in 1911 ("the May Fourth Movement")" [the May $4^{\text {th }}$ Movement began in 1919, not 1911], "Deng Hsiao-ping" [mixing two different transliteration systems of Chinese either 'Deng Xiaoping' or 'Teng Hsiao-p'ing'] (p 268), "literates [?] like Hermann Hesse" (p 269), "to take ... pejorative [?]" (p 284), "a not understandable" [instead of 'unintelligible'?] (p 285), "to extinct them" [instead of 'annihilate'/'exterminate'/'kill'?] (p 285), "week [sic] male anti-heroes" (p 293), "only the dissent generates innovation" (p 295), etc. 
losses after the 'unequal tries' of Aigun (1858) and Peking (1860) with the Tsarist Empire. On the other hand, a settlement with Japan on the four northern islands remains but a vague prospect. Russia's rôle in the Six-Party Talks on the DPRK nuclear programme and the Korean Peninsula may be less publicly visible that China's as host country but stabilising supplies of military spares to the DPRK armed forces to ensure their "defensive potential" highlight Moscow's substantial interest in a minimum of stability in potentially highly fluid surroundings. Nicholas Eberstadt's "Economic Implications of a "Bold Switchover" in DPRK Security Policy Potentialities for Economic Performance in a Still-Socialist North Korea" outlines the considerable room for economic growth in the DPRK even without overturning the régime's political foundations.

The European Union is now China's largest trading partner and one of the largest sources of foreign direct investment in China. This considerable presence in the economic arena is not accompanied by security commitments of similar import and it seems apposite to recall that the eminent security commitments in Asia of the US - regarding Japan, South Korea and Taiwan - all predate the dramatic post-Mao upturn in economic exchanges with China, subtending but not reflecting the background of present-day relations with the China of "Reform and Opening". Bernt Berger and Heather Gilmartin's lengthy "The Quiet Europeans? Appraising Europe's Commitment to East Asian Security" perhaps involuntarily reflects the limits imposed on EU ambitions by both distance and the absence of 'hard' security responsibilities: Much debate on the EU's rôle in the security policy of the region has produced copious Euro-'discourse' and the recognition that the EU's contribution to enhanced security of East would chiefly consist in its instructive experience of successful integration and pooling of sovereignties. Even if this affords the EU no easy seat at East Asia's security top table, the EU's example may yet receive even closer attention from all those in the region who realise that East Asia's many important states stand to lose much more than slivers of national pride if they do not safeguard their impressive progress through co-operation which decisively transcends zero-sum rivalries.

Editing of this volume has been clearly better than that of "Perceptions and Images" but an eagle-eyed wielder of the blue pencil could still have saved several essays from numerous blemishing slip-ups ${ }^{4}$.

Wolfgang Kessler, Peking*

$\mathrm{Eg}$, "economic frames" (p 12), "dimensions of the geographic and geopolitical parameters" [instead of 'dimensions of geography and geopolitics'] (p 14), "Japan still treated as a pariah in large parts of Asia" (p 17) would seem a drastic overstatement, "the internal debates ... has not yet led" (p 23), "crackdowns [?] on the nuclear non-proliferation regime" (p 26), "Green Party KMT (Guomindang)" ... "Blue Party DPP" [gets the match wrong: the KMT are 'blue' and the DPP are 'green'; see the correct combination at p 198] (p 45), "It's" [instead of 'its'] (p 49f), "Foreign Minister Li Xiaoxing" [instead of 'Li Zhaoxing'] (p 220. n 20), "to impeace [?] its neighborhood" (p 225), "principle" [instead of 'principal'] (p 235), "complimentary" [instead of 'complementary'] (p 239).

* The author works at the embassy of the Federal Republic of Germany in the People's Republic of China; this review expresses his personal opinion. 
Franz von Benda-Beckmann / Keebet von Benda-Beckmann / Melanie G. Wiber

Changing Properties of Property

New York, Oxford, Berghahn Books, 2006, 384 S., US \$ 89.95 / £ 45.00,

ISBN 1-84545-139-2

Die vorliegende Aufsatzsammlung ist aus der rechtsanthropologischen internationalen Fachkonferenz "The Properties of Property" hervorgegangen, die im Juli 2003 im MaxPlanck-Institut für ethnologische Forschung in Halle/Saale stattfand. Solche Sammelbände bergen immer die Gefahr in sich, dass verschiedene Themen nur lose nebeneinander stehen, je nach Forschungsschwerpunkt des/der jeweiligen Referenten/in. Glücklicherweise ist dies hier jedoch nicht der Fall: Trotz ihrer Vielzahl ergänzen sich die Aufsätze (von wenigen Ausnahmen abgesehen) gegenseitig und verweisen aufeinander.

Dies verdankt sich nicht zuletzt dem Einführungskapitel „The Properties of Property“, in dem das Herausgeber-Team Franz von Benda-Beckmann, Keebet von Benda-Beckmann und Melanie G. Wiber den roten Faden aufzeigen. Sie fassen die späteren Kapitel unter Bezugnahme auf die zentralen Thesen der Konferenz zusammen und stellen sie in den eigentumstheoretischen Kontext: „Eigentum“ werde in der westlichen Forschung zu sehr auf die eigene juristische Nomenklatur verengt, insbesondere auf die Vorstellung von individuellem Privateigentum. Es müssten darüber hinaus auch die lokalen, oft historisch gewachsenen Vorstellungen von Eigentum berücksichtigt werden. Insbesondere trete Eigentum häufig als Kollektivrecht in unterschiedlicher Form auf, ganz im Gegensatz zur westlichen Dichotomie von Individual- und Gemeineigentum. Land- und Agrarreformen, kulturelle und andere Rechte würden oft anhand ihrer Ausrichtung am westlichen Ideal bewertet, ohne die kulturellen, ökonomischen und ökologischen Besonderheiten vor Ort zu berücksichtigen. Und dies, obgleich der Begriff von Individualeigentum angesichts der umfangreichen Pflichten und Restriktionen, die ihm auferlegt werden, schon längst nicht mehr der „reinen Lehre“ entspreche. Neue Arten von Eigentum seien entstanden und hätten die überkommenen Kategorien des Eigentums strapaziert. Der Eigentumsbegriff sollte daher viel breiter diskutiert werden. Bisher fehle hierfür der theoretische Rahmen. Einen solchen zu erstellen, wolle die Aufsatzsammlung versuchen, um überkommenes Denken aufzubrechen.

In diesem Sinne hinterfragt Charles Geisler zunächst im Kapitel „Ownership in Stateless Places“ die These, dass zeitgenössisches Eigentum einen funktionierenden Staat voraussetze. Er kommt zu dem Schluss, dass Eigentum zwar in soziale, politische und wirtschaftliche Organisationen eingebettet sei, diese Organisationen aber nicht zwingend funktionierende Staaten sein müssten. Esther Kingston-Mann bemängelt in ihrem Beitrag „The Romance of Privatisation and its Unheralded Challenges" die geradezu als Axiom geltende These, dass landwirtschaftlicher Privatbesitz produktiver sei als Kollektivbesitz. Diese These ist für sie ,romantischer Mythos“. Die Autorin legt dar, dass der Weg von Kollektivbesitz zum Individualbesitz westlicher Ausprägung keineswegs mit einer Produktionssteigerung einhergehen müsse. Dies beleuchtet sie in Beiträgen zum Verhältnis von Gemein- 
schafts- zu Privatbesitz in der englischen Geschichte (Auflösung der englischen Allmende), in der spätzaristischen Epoche (Umverteilungssystem im russischen „Mir“ und Stolypinsche Agrarreformen), in der Sowjetzeit (Sowchosen und Kolchosen und die Rolle der „privaten“ Hausgärten) und der postsowjetischen Ära. Die vier historischen bzw. zeitgeschichtlichen Exkurse geben eine sehr gute Einführung und Übersicht zum jeweiligen Thema. Dass hierbei die Umstellung auf Privateigentum nicht unbedingt zu Produktionsfortschritten führt, wird z.B. mit Zahlen zu den massiven Produktionsrückgängen infolge der Privatisierungen der Post-Sowjetzeit belegt. Hier ließe sich freilich einwenden, der Produktionsrückgang habe gerade wegen der Unvollständigkeit der Privatisierung stattgefunden $(90 \%$ des Getreideanbaus finden immer noch in den ehemaligen Staatsbetrieben statt). Solche denkbaren Gegenargumente nehmen dem Aufsatz jedoch nichts von seinem Charakter einer wertvollen Diskussionsgrundlage, um die These der Überlegenheit von Privateigentum zu anderen Eigentumsformen zu hinterfragen.

Pauline E. Peters nimmt mit ihrem Thema „Beyond Embeddedness: a Challenge Raised by a Comparison of the Struggles Over Land in African and Post-socialist Countries“ den Faden des Eingangskapitels auf: Der Eigentumsbegriff, so betont sie, müsse in die lokalen, gewachsenen Strukturen eingefügt ("embedded") werden. Die traditionelle Entwicklungsthese, dass die Einführung des westlichen, individuellen Eigentumsrechts anstelle etwa von Stammesrecht quasi automatisch Produktivitätszuwachs und wachsenden Wohlstand herbeiführe, sei durch eine Reihe von Feldstudien widerlegt. Auch in den postsozialistischen Staaten habe die sogenannte „Dekollektivierung“ nicht automatisch zu Erfolg geführt. Vielmehr würden diese Transitionsprozesse oftmals von einflussreichen Cliquen (Beamten, Stammeshäuptlingen, Kolchoseführern usw.) dazu genutzt, ihre Besitzund Herrschaftsansprüche zu steigern.

Thomas Sikor beschäftigt sich in seinem Beitrag „Land as Asset, Land as Liability“ anhand zweier Fallbeispiele in Tschechien und Polen mit den Verpflichtungen, die mit der Restituierung von Land einhergehen können. So wurden in den Weißen Karpaten Wiesenflächen an die ehemaligen Besitzer/innen bzw. deren Erben unter strengen Bewirtschaftungsauflagen restituiert. Hierdurch sollten ökologisch wertvolle Orchideenbestände geschützt werden. Während Bewirtschaftungsbeschränkungen ursprünglich entweder nicht eingehalten oder aber die Bewirtschaftung sogar als nicht lohnend aufgegeben wurden, funktioniert dies nach Einführung von Ausgleichszahlungen und Kontrollen mittlerweile einigermaßen. Hingegen sei ein vergleichbares Projekt in Piasczno bei Warschau mangels Kontrollen völlig gescheitert. Die Verknüpfung von Besitzrechten mit Besitzpflichten könne eben nur bei entsprechenden staatlichen Maßnahmen wie Fördergeldern und Kontrollen funktionieren.

Das Kapitel von Oane Visser über „Property, Labour Relations and Social Obligations in Russia's Privatised Farm Enterprises" schildert die Entwicklung der ehemaligen Genossenschaften (Kolchosen) und Staatsbetriebe (Sowchosen) in Russland infolge der Dekollektivierung in den neunziger Jahren. Interessanterweise sei die Produktivität der Betriebe zumindest statistisch um $60 \%$ zurückgegangen. Diese existierten meist mehr oder weniger 
unverändert weiter, eine Ausgründung der ehemaligen „Genossen“ hat nur in den seltensten Fällen stattgefunden. Ursache hierfür sei zum einen, dass keine Realaufteilung stattgefunden habe - der Einzelne verfüge nur über einen abstrakten Besitzanspruch, nicht über konkrete Eigentumsrechte an Grund und Boden oder Produktionsmitteln. Zum anderen lägen die Informationen über Landreform-Gesetze sowie die Möglichkeit der Zuweisung von Grundstücken und Produktionsmitteln beim Betriebsführer, der mit diesem Herrschaftswissen die Kontrolle des Betriebes faktisch weiterhin innehabe. Zugleich habe sich die Schattenwirtschaft auf den „Hausgärten“ der Betriebsmitglieder weiter verstärkt, ${ }^{1}$ wobei bedeutende Teile der Betriebsressourcen (Maschineneinsatz, Arbeitseinsatz, Heu etc.) auf diese „Privatwirtschaft“ umgelenkt würden. Letzten Endes sei es somit nur zu oberflächlichen Veränderungen in den Sowchosen und Kolchosen gekommen.

John R. Eidson befasst sich in seinem Aufsatz „Cooperative Property at the Limit“ mit der Entwicklung landwirtschaftlicher (Zwangs-)Genossenschaften, den so genannten LPG (Landwirtschaftliche Produktionsgenossenschaft) in der DDR. Leider liefert dieser Beitrag wenig Neues - Aufbau und Entwicklung der LPG sind beileibe kein neues Thema. Der sehr viel spannendere und aktuellere Themenkreis, wie sich die ehemaligen LPG seit 1990 weiter entwickelt haben, wird hingegen nur am Rande berührt. Auch zum theoretischen Gesamtrahmen trägt dieser Aufsatz wenig bei. Vielmehr kann man sich des Eindrucks nicht erwehren, dass der Autor sich in seinen Forschungen intensiv mit ehemaligen Führungskräften der Kollektivgemeinschaften auseinandergesetzt und von letzteren ein tendenziell einseitiges, zu positives Bild der damaligen Verhältnisse übernommen hat.

In einem interessanten Beitrag analysiert Toon van Meijl als Fallbeispiel unter dem Titel „Who Owns the Fisheries? Changing Views of Property and its Redistribution in Post-colonial Maori Society “ den langjährigen Streit um die Fischereirechte der Maori in Neuseeland aus dem Blickwinkel der Eigentumstheorie. In der Debatte würden Gesichtspunkte einer gewandelten Beziehung der Maori zum Eigentum durch die Kolonialisierung und einer Verschiebung der Eigentumskategorien durch die Einführung von Fischfangquoten durch die Regierung außer Acht gelassen. Die Debatte habe sich auf die Definition von „Stamm“ zentriert, ohne dabei die gewandelten Beziehungen der Maori, von denen heute $80 \%$ in urbanen Verhältnissen leben und deren traditionelle Bindungen sich verändert haben, einzubeziehen. Die Lösung des Problems bewege sich im Spannungsfeld zwischen historischer und sozialer Gerechtigkeit. Ersteres bedeute Wiedergutmachung für in der Vergangenheit erlittenes Unrecht, wovon nur eine geringe Anzahl der Maori, die noch traditionell leben, profitieren würde. Letzteres bedeute anzuerkennen, dass sich die Beziehungen der Maori zum Eigentum durch die Kolonisierung stark verändert hätten; deshalb seien die in den Städten lebenden Maori bei der Zuteilung von Rechten und Ausgleichszahlungen zu berücksichtigen. Die gegenwärtige Strategie setze den Schwerpunkt vor allem privat gehalten werden. Dieser „Privatanteil“ hatte sich mittlerweile auf durchschnittlich 0,5 Hektar vergrößert. 
auf Wiedergutmachung für vergangenes Unrecht. Die Herausforderung bleibe, einen dauerhaften Ausgleich zwischen historischer und sozialer Gerechtigkeit zu finden.

Anhand eines weiteren Beispiels aus der südlichen Hemisphäre, Minangkabau (Indonesien), hinterfragen Franz und Keebet von Benda-Beckmann im sehr aufschlussreichen Kapitel „How Communal is Communal and Whose Communal is It?“ das geläufige Verständnis von Gemeineigentum. In Minangkabau koexistierten seit langem ,pusako“, ererbtes Eigentum, das allen Angehörigen eines Matriclans zustehe, und „ulayat“, Land, das den Dorfbewohnern gemeinsam zustehe. Eine Analyse dieser Systeme im historischen Kontext und ihre Beeinflussung durch andere Faktoren, wie den Islam oder die Kolonialisierung, ermöglicht es, aufzuzeigen, dass die gängigen Konzepte von Gemeineigentum meist zu kurz griffen. Oft werde dabei übersehen, dass Gemeineigentum nicht gleich Gemeineigentum sei und ferner trotz seines Namens auch Individualrechte in Bezug auf das Gemeineigentum umfassen könne. Dies widerlege auch die gängige Auffassung, Gemeineigentum sei aus dem Blickwinkel der wirtschaftlichen Entwicklung eher abzulehnen. Ein falsches Verständnis von Gemeineigentum habe auch zu einer Fehlinterpretation der beiden traditionellen Eigentumskategorien in der Literatur geführt. Wie das Beispiel Minangkabau zeige, müsse auch Gemeineigentum vor den weiteren sozialen, wirtschaftlichen und politischen Entwicklungen, aber auch den breiteren rechtlichen Strukturen gesehen werden. Gemeineigentum als mehr oder minder homogene Eigentumskategorie zu interpretieren, sei zum Scheitern verurteilt.

Die Reise auf den Spuren des Eigentums führt im Kapitel „Moving Borders and Invisible Boundaries: a Force Field Approach to Property Relations in the Commons of a Mexican ejido“ nach Mittelamerika. Hier untersuchen Monique Nuijten und David Lorenzo das Schicksal von Land im Gemeineigentum beispielhaft an dem „ejido“ La Canoa. Obwohl im Beitrag weitläufig vom Begriff ,ejido“ Gebrauch gemacht wird, erfolgt leider keine Übersetzung oder Definition des Begriffes. Es wird lediglich von den Rechten und der inneren Organisation des ,ejido“ berichtet. Die faktenreiche und mit Karten versehene Studie zeichnet die Entwicklung in La Canoa aus historischer Sicht im sozioökonomischen Kontext nach, lässt aber die Einbettung in die eigentumstheoretischen Überlegungen, die das Buch anstellen möchte, leider etwas zu kurz kommen.

Eloquent und anschaulich schildert Deborah James anschließend in "The Tragedy of the Private; Owners, Communities and the State in South Africa's Land Reform Programme" die Fallstricke der Landreformen, die zwischen der Neuverteilung des Privateigentums und dem traditionellen Staatseigentum die richtige Balance finden müssten. Obwohl von Anfang an durch die Aufteilung der Reform in die Kategorien Restitution, Neuverteilung und Pachtrechtsreform versucht worden sei, den unterschiedlichen Zielgruppen der Reformen und dem komplexen Zusammenspiel von moralischen und ökonomischen Motivationen gerecht zu werden, sei dies bislang noch nicht gelungen. Vielmehr sei teilweise sogar mehr Chaos verursacht worden als zu Zeiten des Staatseigentums. Vieles sei auf mangelndes Management zurückzuführen. Vom Standpunkt des Eigentums her betrachtet, sei Südafrika ein Land in der Übergangsphase, in der alles neu entwickelt werde. 
Die sich so ergebenden Modelle hätten alt und traditionell, privat und öffentlich auf unerwartete Weise kombiniert. Die Armen und Landlosen scheinen jedoch aufgrund der übergroßen Komplexität der Modelle von der Reform ausgeschlossen.

Ebenfalls an einem afrikanischen Beispiel, Madagaskar, erläutert Frank Muttenzer im Kapitel „The Folk Conceptualisation of Property and Forest-related Going Concerns in Madagascar“ das Spannungsverhältnis zwischen dem Volksverständnis und den neoinstitutionalistischen Politik-basierten Konstruktionsprinzipien und analytischen Konzepten von Eigentum. Eigentumsverhältnisse hinsichtlich der Benutzung und der Kontrolle von Waldressourcen seien in Madagaskar die Folge zweier Arten des Pluralismus: zum einen eines Pluralismus der gesellschaftlichen Organisation und zum anderen eines Rechtspluralismus mit verschiedenen unabhängigen, auf den gleichen Sachverhalt anwendbaren normativen Ordnungen. Anhand von Waldbelangen werden die Auswirkungen der sich widersprechenden Vorstellungen von Eigentumsrechten in der Praxis dargestellt und aufgezeigt, dass das Volksverständnis von Eigentum nicht gestaltet werden könne, da die Prinzipien vom gerechten Geschäftsvorgang außerhalb der Diskussion lägen. Frank Muttenzer lehnt die eigentumstheoretischen Überlegungen zur Interpretation des Eigentums als „Bündel von Rechten" anders als die meisten Autorinnen und Autoren des Sammelbandes für das Beispiel Madagaskar ab.

Am Beispiel der Wasserrechte in Colorado, USA, schildert Edella Schlager im Kapitel "Property Rights, Water and Conflict in the Western U.S." die Schwierigkeiten, die auch in westlichen Ländern bei verschiedenen, nicht auf einander abgestimmten Eigentumssystemen entstehen können. Sie erläutert die historische Entwicklung unterschiedlicher, mitunter sich auch widersprechender Nutzungsrechte am Grundwasser und an Oberflächengewässern. Solche Widersprüche trügen zur Wasserknappheit bei. Ein einheitliches System zur Wassernutzung zu entwickeln erfordere freilich ein Umdenken bei den Beteiligten.

Zurück in Europa befasst sich Gísli Pálsson unter dem Titel "Appropriating Family Trees: Genealogies in the Age of Genetics" am Beispiel des sog. "Buches der Isländer" mit der Frage, welche Eigentumsqualität genealogische Informationen haben und wie der Zugriff auf sie geregelt werden solle. Auch im Bereich der biomedizinischen Ressourcen habe man es mit einem "Bündel von Rechten" zu tun, die die Zugangsrechte und die Berechtigungen an den Ressourcen regelten.

Im Schlusskapitel beleuchtet die Mitherausgeberin Melanie G. Wiber unter dem Titel „Cultural Property, Repatriation and Relative Publics: Which Public? Whose Culture?“ Ansprüche auf kulturelles Eigentum anhand zweier Beispiele aus Nordamerika. Im ersten Fall, dem „Fair Winds“-Wassertrommelfall, wurden indigene Gegenstände, die dem Museum der Universität von Winnipeg von Nachkommen des ursprünglichen indigenen Eigentümers überlassen waren, von anderen indigenen Personen aus dem Museum entfernt und weiteren indigenen Personen zurückgegeben. Im zweiten Fall ging es um Rechte an den ca. 9000 Jahre alten, sterblichen Überresten eines menschlichen Vorfahren, die in der „Spirit Cave“ in Nevada gefunden worden waren. Wie die Verfasserin resümmiert, könne ein Abrücken von der Zweiteilung privat/öffentlich unter Zuhilfenahme von ,relativer 
Öffentlichkeit“ einen Beitrag dazu leisten, das Geflecht von Rechten im Falle einer Vielzahl von Anspruchssteller(inne)n zu entwirren.

Das Buch versammelt für die Eigentumstheorie lesenswerte neue Denkanstöße. Sie helfen, wie es der Buchtitel verspricht, das Eigentum in neuem Licht zu sehen, und zwar betont kontextbezogen in unterschiedlichen Rechts- und Kulturumfeldern. Sind die meisten der Beiträge für sich bereits informativ, so schaffen die Internationalität und die Diversität der Beispiele, die sich nicht auf Landeigentum beschränken, sondern einer Reihe von anderen Eigentumsformen nachgehen, einen Mehrwert in der Zusammenstellung. Die gegenüber dem hohen Niveau der meisten Aufsätze etwas abfallende Darstellung einiger weniger Beiträge tut dem letztlich keinen Abbruch. Das Buch sei all denen empfohlen, die sich mit Eigentum unter dem einen oder anderen Aspekt befassen und neue Blickwinkel kennen lernen wollen.

Sabine Pittrof, Frankfurt am Main

Martin Scheuermann, Ingelheim am Rhein

\section{Walter Gieler (Hrsg.)}

\section{Die Außenpolitik der Staaten Afrikas. Ein Handbuch}

Paderborn et.al., Ferdinand Schöningh Verlag, 2007, EUR 58.00;

ISBN: 978-3-506-76473-7

Walter Gieler nimmt sich mit der Herausgabe dieses voluminösen Handbuchs einer Thematik an, die bisher nicht im Mittelpunkt der (politikwissenschaftlichen) Afrikaforschung stand. Die Außenpolitiken der Staaten Afrikas ist, soweit ersichtlich, bisher noch nicht systematisch und umfassend dargestellt und analysiert worden.

Wie ist das zu erklären? Es dürfte vor allem daran liegen, dass die meisten afrikanischen Staaten bisher auf der weltpolitischen Bühne nicht durch bedeutende Außenpolitiken aufgefallen sind. Die außenpolitische Orientierung vom Erreichen der Unabhängigkeit bis zum Ende des Kalten Krieges (symbolisiert durch den Fall der Berliner Mauer 1989) war maßgeblich durch die bipolare Weltordnung geprägt. Die westlichen Staaten waren bemüht, den Einfluss der Sowjetunion auf dem Kontinent zu begrenzen. Dafür waren sie auch bereit, über z. T. eklatante Menschenrechtsverletzungen und Demokratiedefizite hinwegzusehen. Es wurden sowohl blutrünstige Diktatoren (wie Kaiser Bokassa in der Zentralafrikanischen Republik oder Mobutu in Zaire) als auch autoritäre Einparteiensysteme oder Militärregierungen (zeitweilig) unterstützt, solange sie sich nicht dem sowjetischen Lager zuwandten.

Nach dem Ende des Ost-West-Konflikts hat Afrika an strategischer Bedeutung für den Westen deutlich verloren. Die wenigen Ausnahmen sind Ägypten (wichtiger, wenn auch abnehmender Einfluss im Nahen Osten) und das Horn von Afrika, wo vor allem Kenya und Äthiopien eine Rolle als bedeutende Stabilitätsanker im Kampf gegen den internationalen 
Terrorismus spielen (Somalia, Sudan). Die geringe außenpolitische Bedeutung der afrikanischen Staaten zeigt sich unter anderem daran, dass sowohl die USA als auch Großbritannien keine klare und systematische Afrikapolitik nach dem Ende des Kalten Krieges betrieben haben. In beiden Staaten - wie auch in der EU - spielte der Kontinent mit wenigen Ausnahmen (Südafrika, Nigeria, Maghrebstaaten) kaum eine Rolle. Gegenbeispiele sind Frankreich und - in den letzten Jahren - die VR China.

Walter Gieler hat sich in der Tat mit der Vorlage des Handbuchs einer monumentalen Aufgabe gewidmet, die trotz ihrer - kaum vermeidbaren - Defizite Anerkennung verdient. Er hat insgesamt 40 Wissenschaftler eingeworben, um die 54 Staaten abzudecken. Allein diese Bandbreite an Autorinnen und Autoren ist positiv zu vermerken. Es ist dem Handbuch durchaus gelungen, ,eine schnelle und differenzierte Orientierung in dem komplexen Bereich der afrikanischen Außenpolitiken“ zu ermöglichen, wie der Herausgeber beansprucht (S. 16). Der weitergehende Anspruch, eine „wissenschaftliche Lücke“ geschlossen zu haben, wäre mit so einem Projekt allerdings kaum möglich. Die meisten Beiträge bieten eine Bestandsaufnahme, keine wissenschaftliche Analyse. Das wäre auch zu viel verlangt.

In der Regel folgen die Beiträge einem inhaltlichen Schema. Der tabellarischen Darstellung der wichtigsten historischen Grunddaten folgt eine allgemeine historische Einführung in das jeweilige Land. Daran schließt sich ein Abschnitt über die Bestimmungsfaktoren der Außenpolitik und häufig noch ein Kapitel über außenpolitische Entscheidungsprozesse an. Darauf aufbauend werden die Sicherheitspolitik und die Politik im Rahmen internationaler Organisationen dargestellt. Die Länderbeiträge enden mit der Darstellung von Perspektiven einer zukünftigen Außenpolitik und einer teilweise erfreulich umfangreichen Bibliographie. Dieser Aufbau ist sicherlich sinnvoll, wenn er denn durchgehalten würde. Damit kommen wir zu einem wesentlichen Problem des Bandes: Die sehr unterschiedliche Qualität der Beiträge. Gleich das erste Land - Ägypten - orientiert sich nicht an diesem Schema (das gilt u.a. auch für Mauretanien sowie São Tomé und Principe). Auf eine entsprechende Gliederung wurde ganz verzichtet. Die Länge der Beiträge spiegelt die Bedeutung der Staaten oft nicht wider. So werden dem Schwergewicht Ägypten nur neun Seiten eingeräumt, während marginalisierte Leichtgewichte wie die Komoren mit zehn Seiten aufwarten. Wenig verständlich ist auch, warum Südafrika mit zehn Seiten, Tanzania aber mit 17 Seiten bedacht wird, während Staaten wie Mosambik (6) und Mali (5) mit deutlich weniger Platz auskommen müssen. An fehlendem Material dürfte es nicht gelegen haben.

Die inhaltliche Qualität variiert - wie es bei solchen umfangreichen Projekten wohl nicht zu verhindern ist - signifikant. Wie fundiert ein Beitrag ist, stellt sich rasch heraus. Es gibt eine ganze Reihe von kenntnisreichen und umfassenden Darstellungen. In anderen Fällen ist die geringer ausgeprägte Substanz hingegen nicht zu übersehen. Nicht selten werden fehlende Kenntnisse über die Außenpolitik damit überdeckt, indem alle möglichen anderen Informationen aufgenommen werden, die mit dem Thema zumeist nichts oder nicht viel zu tun haben. Warum z. B. die Information, dass Malawi ,weltweit derzeit über 14 Botschaften und ein Generalkonsulat" verfügt (S. 249) von Relevanz sein soll, erschließt sich dem Leser nicht. Stattdessen fehlt die wichtige Information, dass Malawi seit 1965 
diplomatische Beziehungen zu Taiwan unterhielt und dieses Land die Finanzierung eines Teils des Repressionsapparates des Autokraten Hastings Banda (1964-1994) übernommen hatte. Auch die Neuausrichtung der malawischen Außenpolitik unter Bakili Muluzi in Richtung arabische Welt sucht man vergebens. Hingegen ist der Beitrag zu Kenya aus der Feder desselben Autors hervorragend. Im Beitrag über die Republik Kongo werden die auch außenpolitisch wichtigen, ersten demokratischen Wahlen gar nicht erst erwähnt (vgl. S. 206, S. 210 f.). Die unrühmliche Rolle, die Frankreich bei dem gewaltsamen Sturz der (zunächst) demokratisch legitimierten Regierung unter Pascal Lissouba spielte und die französische Unterstützung für den ehemaligen Autokraten Denis Sassou-Nguesso, der den Bürgerkrieg schließlich für sich entscheiden konnte, bleiben im Dunkeln. Diese Problematik wäre jedoch sehr viel wichtiger und interessanter als einige historische Details aus der Zeit nach der Unabhängigkeit, da sie unmittelbaren Einfluss auf die Außenpolitik der Republik Kongo nach 2003 hat. Das sind nur einige willkürlich herausgegriffene Beispiele.

Es wäre möglicherweise sinnvoll gewesen, die außenpolitischen Komponenten der Afrikanischen Union (AU) und ihrer Vorgängerin, der Organisation für Afrikanische Einheit (OAU) sowie die Southern African Development Cooperation (SADC) und die Economic Community of West African States (ECOWAS) in jeweils eigenständigen Kapiteln $\mathrm{zu}$ beleuchten. Natürlich haben diese bisher nur ein (sehr) begrenztes außenpolitisches Profil entwickelt, aber trotzdem sollten sie nicht nur in den Länderbeiträgen Berücksichtigung finden. Vor allem auf dem Feld der Sicherheitspolitik spielen sie eine zunehmend wichtige Rolle.

Insgesamt trägt das Handbuch eine Fülle von Fakten zu einem Themenkomplex zusammen, der bisher in der (politikwissenschaftlichen) Afrikaforschung unterbelichtet war. Wie jedes derart angelegte Handbuch wird es zwar relativ schnell an Aktualität verlieren, bleibt aber auf jeden Fall ein wichtiges Referenzwerk und kann somit der Forschung gute Dienste leisten.

Heiko Meinhardt, Hamburg

\section{Mark Sidel}

\section{Law and Society in Vietnam}

The Transition from Socialism in Comparative Perspective Cambridge, New York, Melbourne, Madrid, Cape Town, Singapore, Sao Paolo, Delhi, Cambridge University Press, 2008, XII, 256, EUR 60,00; ISBN 978-0-521-85052-0

Es geht in diesem Buch um jüngere Rechtsentwicklungen in Vietnam, einem Staat, der durch eine kommunistische Bewegung nationale Unabhängigkeit und Einheit gefunden hat und bis heute von fortdauernder, auch formal festgeschriebener Dominanz seiner kommunistischen Partei geprägt ist. Und ebenso in seinem Selbstverständnis von Jahrzehnte langem Befreiungskampf gegen erdrückende fremde Übermacht, dem dabei schlussendlich 
errungenen Sieg wie auch den fortdauernden Wunden. Vietnam hat sich in den letzten Jahren ungeachtet des kommunistischen Credo durch eine Umgestaltung seines Wirtschaftssystems vitalisiert, ist in Teilen (dies ebenso geographisch gemeint wie sektoriell) wirtschaftlich erblüht - und leidet unter den Widersprüchen, die wirtschaftliche (Teil-) Liberalisierung, Kapitalorientierung, Rasanz der Steigerung des Lebensstandards für Erfolgreiche bei gleichzeitiger Aufrechterhaltung eines ideologischen Monopolanspruchs mit sich bringen. Nicht nur die Wirtschaft, auch das Recht hat sich nachhaltig verändert in Vietnam, und es steht heute vor großen Herausforderungen. Sie sind teilweise extern induziert, institutionell verlangt oder durch die von Vietnam gesuchten internationalen Partner nahe gelegt; teilweise rufen auch schon Akteure der sich bildenden Zivilgesellschaft danach. Ausländische Modelle werden auch von den einstweilen weithin alternativenlosen herrschenden Kreisen Vietnams nachgefragt, sollen nachmodelliert werden und rufen dann doch immer auch Grundsatzfragen hervor: Auch Rechtsreformen in kleinteiligen oder technisch erscheinenden Bereichen führen leicht $\mathrm{zu}$ prinzipiellen Erörterungen über Rechtssicherheit, Transparenz, Rechtsschutz, damit dann über die Rolle und Unabhängigkeit von Gerichten und die Legitimation der Rechtssetzer. Rechtsstaatliche und demokratische Ideale kommen so im Grundsätzlichen ins Spiel und stellen tendenziell das Monopol einer Partei in Frage. Alle Beteiligten nötigt das zum Spagat, zur Behutsamkeit und einem besonnenen Umgang mit dem Faktor Zeit. Von Transitional Constitutionalism spricht Mark Sidel.

Sein Buch untersucht nicht systematisch die Wechselwirkungen zwischen Recht und Gesellschaft, sondern berichtet über Recht, den Umgang damit, Veränderungen und politische Reaktionen hierauf aus Staat und Gesellschaft Vietnams. Sicher auch deswegen hat der Autor einen Untertitel gewählt, der indes nicht wirklich treffend ist: Von einem Übergang „from socialism“ - wohin? - kann in Vietnam nicht die Rede sein. Dort geht es um Veränderungen (auch des Rechts, teils, wie gesagt, in Anverwandlung außersozialistischer Vorstellungen) ,innerhalb“ eines sozialistischen Systems. Und die angekündigte komparative Perspektive: Dazu bewendet es bei gelegentlichen Hinweisen darauf, dass die Dinge in China ähnlich oder ,vergleichbar“ lägen; andere Vergleiche kommen kaum vor. Der Ankündigungstext des Buches spricht vom ,struggle to build a rule of law in one of the world's most dynamic and vibrant nations“. Aber auch um die ,rule of law”, das Ensemble damit anderwärts oder teilweise auch in Academia und Politik Vietnams verbundener Vorstellungen, geht es Sidel nicht eigentlich, sondern vielmehr um die ,role of law“, eine Rolle für das Recht im Rahmen der Umgestaltung in Vietnam, um das Recht als Steuerungsinstrument, weniger als ein Sicherungsinstrument für Freiräume gesellschaftlicher Akteure. Das ist insofern folgerichtig, als Sidel vor allem Deskription bietet (durchaus mit interessanten Kommentierungen) und nicht Perspektiven oder gar den Entwurf von aus den geschilderten Entwicklungen möglicherweise resultierenden künftigen Szenarien.

Mark Sidel ist Hochschullehrer an der Universität of Iowa, hat an verschiedenen Hochschulen (auch) über Recht in Vietnam gelehrt und langjährige Erfahrungen bei der Wahrnehmung von Aufgaben für zahlreiche sog. Geberinstitutionen, die Vereinten Nationen, die 
Weltbank, Stiftungen sowie für staatliche Stellen in den USA und in Vietnam gesammelt, war also beratend, mitgestaltend und Mittel verwaltend in den von ihm geschilderten Prozessen tätig. Das kommt dem Buch außerordentlich zugute, weil es erkennbar zu bester Kenntnis der politischen Rahmenbedingungen und der innerhalb dieser Bedingungen agierenden Personen und Kräfte in Vietnam geführt hat. Viele Zitate zeugen davon, auch viele vietnamesische Quellen aus Printmedien und Internet werden erwähnt und erschlossen.

Das Buch ist in acht Kapitel gegliedert, denen eine Einleitung vorangeht. Es befasst sich mit dem Mitte der 80er Jahre des vergangenen Jahrhunderts einsetzenden Veränderungsprozess in Vietnam bis heute und stellt in den Mittelpunkt im Grunde drei Fragen: Diejenige nach der Bedeutung von Verfassungsrecht, diejenige nach Wirtschaftsrecht und seiner Bedeutung für „Entwicklung“ und diejenige nach Bürgerrechten - so die Einleitung, S. 16 f. Diese Fragen werden aber nicht als solche entfaltet und abgearbeitet, sondern der Autor vermerkt, dass es in den acht Abschnitten jeweils um eine oder mehrere dieser Fragen zugleich gehe. Das ist auch zutreffend. Die einzelnen Abschnitte sind, wie angedeutet wird, jedenfalls in Teilen in anderen Zusammenhängen oder aus anderen Anlässen entstanden, sodann aufbereitet und zusammengestellt worden. Die drei genannten Leitfragen sind also nicht gliederungsprägend und werden auch nicht einer irgendwie gearteten Bilanz zugeführt; ein Schlusskapitel gibt es nicht.

Man kann sich dennoch in dem Buch ganz gut zurecht finden, denn durchschnittlich alle 1, 2 oder 3 Seiten sind in den Text Subüberschriften eingestreut, die ungefähr darüber informieren, worum es gerade geht, nicht aufgenommen zwar in eine Inhaltsübersicht, aber doch bei der Durchsicht des Bandes hilfreich. So findet der Leser den Zugang zu vielen Einzelheiten und zu auf das Recht oder die Rechtspolitik bezogenen Diskussionssegmenten, quer durch die Rechtsordnung, vor allem bezogen auf Handels-, Wirtschafts- und Arbeitsrecht, aber auch zur Rolle der Anwaltschaft, zur Polizei, zur Presse, zum Strafrecht. Auch zu der die vietnamesische Diskussion seit längerem umtreibenden Frage der Verfassungsgerichtsbarkeit, der Normenkontrollzuständigkeit insbesondere - sie ist exemplarisch für die mit dem Prozess der Rechtsreform in Vietnam untrennbar verwobene, ihn immer wieder offen oder subkutan beeinflussende Gewaltenteilungsproblematik - finden sich interessante Hinweise, wenngleich eher nicht auf neuestem Stande.

So ist das Buch eine von einem guten Sachkenner dankenswerterweise bereitgestellte Fundgrube, mehr aber nicht. Dass die Einleitung oberflächlich bleibt - auf etwa 18 Seiten schildert sie vor allem innervietnamesische Debatten weit vor dem Reformprozess, führt in die 50er und 60er Jahre zurück -, dass die acht Kapitel unzureichend aufeinander abgestimmt sind, auch in sich teils des systematischen Aufbaus ermangeln, dass schließlich ein Schlusskapitel gänzlich fehlt - diese drei Umstände sind überraschend und enttäuschend auch bei „Cambridge Studies in Law and Society“. Dennoch haben hier alle am Fortgang der Rechtsentwicklung in Vietnam Interessierten eine wichtige Informationsquelle erhalten, wenn auch kaum ,in comparative perspective“. 